\title{
Effects of Pre- and Postharvest Calcium Treatments on Shelf Life and Postharvest Quality of Broccoli Microgreens
}

\author{
Liping Kou \\ College of Food Science and Engineering, Northwest A\&F University, \\ Yangling, Shaanxi 712100, China
}

Tianbao Yang ${ }^{1}$

Food Quality Laboratory, United States Department of AgricultureAgricultural Research Service, Beltsville, MD 20705

Xianjin Liu

Institute of Food Quality and Safety, Jiangsu Academy of Agricultural Sciences, Nanjing, Jiangsu 210014, China

\section{Yaguang Luo}

Food Quality Laboratory, United States Department of AgricultureAgricultural Research Service, Beltsville, MD 20705

Additional index words. broccoli microgreens, calcium chloride, calcium lactate, calcium amino acid, quality, shelf life

\begin{abstract}
We reported previously that the preharvest treatment of broccoli microgreens with $10 \mathrm{mmol} \cdot \mathrm{L}^{-1}$ calcium chloride $\left(\mathrm{CaCl}_{2}\right)$ increased the yield and postharvest quality. The objective of this study was to investigate whether other calcium forms have the similar effect, in particular, after postharvest dip in calcium solution. Our results are as follows: 1) Preharvest spray without postharvest dip: Both $20 \mathrm{mmol} \cdot \mathrm{L}^{-1}$ calcium lactate (Ca lactate) and calcium amino acid (Ca AA) chelate significantly improved broccoli microgreens quality and inhibited microbial populations as compared with the wateronly control during storage at $5{ }^{\circ} \mathrm{C}$ for 21 days. However, they were less effective than $10 \mathrm{mmol} \cdot \mathrm{L}^{-1} \mathrm{CaCl}_{2}$. 2) Postharvest dip without preharvest spray: The microgreens sprayed with water-only control were dipped in $0,25,50$, or $100 \mathrm{mmol} \cdot \mathrm{L}^{-1} \mathrm{Ca}$ lactate solution containing $100 \mu \mathrm{L} \cdot \mathrm{L}^{-1}$ chlorine immediately after harvest. During storage at $5^{\circ} \mathrm{C}$ for 14 days, $50 \mathrm{mmol} \cdot \mathrm{L}^{-1} \mathrm{Ca}$ lactate dip showed the highest overall quality and lowest tissue electrolyte leakage. 3) Preharvest spray and postharvest dip: Combined preharvest $10 \mathrm{mmol} \cdot \mathrm{L}^{-1} \mathrm{CaCl}_{2}$ spray and postharvest $50 \mathrm{mmol} \cdot \mathrm{L}^{-1} \mathrm{Ca}$ lactate dip resulted in better postharvest quality than individual pre- or postharvest calcium treatments. However, the preharvest $10 \mathrm{mmol} \cdot \mathrm{L}^{-1} \mathrm{CaCl}_{2}$ spray without postharvest dip displayed a best overall visual quality and longest storage life. Our data indicate that pre- and postharvest calcium treatments have positive effect on maintaining the microgreens quality and extending shelf life. However, current postharvest dip/spinning/drying method profoundly reduces the shelf life due to mechanical damages. Technologies to optimize microgreens wash are needed to provide ready-to-eat product. Alternatively, the wash step can be avoided when the microgreens are grown under controlled settings.
\end{abstract}

Microgreens are cotyledonary-leafed seedlings harvested within 10-20 d after vegetable seed germination. In recent years,

\footnotetext{
Received for publication 18 Sept. 2015. Accepted for publication 13 Nov. 2015

We thank Ernie Paroczay for assistance in planting microgreens, and Ellen Turner and Frances Trouth for reviewing and revising the manuscript before its submission.

Use of a company or product name by the U.S Department of Agriculture does not imply approval or recommendation of the product to the exclusion of others that may also be suitable.

${ }^{1}$ Corresponding author. E-mail: tianbao.yang@ ars.usda.gov.
}

growing microgreens have become a more common practice for urban farming because of their easiness to handle indoors, and their high nutritional value and sensory appeal (Kou et al., 2013, 2014a; Xiao et al., 2012). However, their commercial production and marketing is limited by their short shelf life due to rapid quality deterioration (Berba and Uchanski, 2012; Chandra et al., 2012; Kou, et al., 2013). Furthermore, since fresh-cut products are marketed as "ready-to-eat" with no need for a sterilization or pasteurization step, wash is a critical process in the preparation of fresh-cut produce and is often the only step. Wash removes foreign materials as well as tissue fluids and reduces microbial populations (Simons, 2001). To provide more affordable ready-to-eat microgreens to a broader market, it is necessary to develop chlorine wash methods, which can maintain postharvest quality and extend shelf life.

Calcium is important for plant growth and development by maintaining and modulating various cellular functions (Conway et al., 2002; Palta, 1996). Calcium alters intracellular and extracellular processes, resulting in retarded ripening as exemplified by lower rates of color change, softening, and $\mathrm{CO}_{2}$ and ethylene production, increase in sugar, and reduction in total acid content (Conway, 1987; Manganaris et al., 2005; Raese and Drake, 1993). The pre- and postharvest application of calcium salts has been used successfully in many fresh fruits to reduce loss of firmness and slow down the ripening process (Floros et al., 1992; Holb et al., 2012; Mohammed et al., 1991; Saftner et al., 1998; Souty et al., 1995). $\mathrm{CaCl}_{2}$ has been primarily used for preharvest treatment. When it is used in fresh-cut products, it may cause a bitter aftertaste in foods (Bolin and Huxsoll, 1989). However, $\mathrm{Ca}$ lactate treatment does not show negative effect on flavor. Therefore, $\mathrm{Ca}$ lactate has been suggested as a potential alternative firming additive for use in freshcut fruits (Luna-Guzmán and Barrett, 2000; Yang and Lawsless, 2005). Martín-Diana et al. (2005) also compared the efficacies of $\mathrm{Ca}$ lactate and chlorine wash treatments of fresh-cut lettuce and carrots during storage at $4{ }^{\circ} \mathrm{C}$ over $10 \mathrm{~d}$ and found that there was no significant differences between treatments. $\mathrm{Ca}$ AA chelate formulations represent another Ca source that has been used in the food and/or nutritional industries (Saftner et al., 2003). Ca AA chelate is not corrosive to processing equipment and is more likely to penetrate deeply into plant tissues. A postharvest Ca AA dip maintained firmness and doubled the shelf life of intact honeydew fruit (Lester and Grusak, 2001, 2004). Currently, the potential for use of $\mathrm{Ca}$ lactate and $\mathrm{Ca} \mathrm{AA}$ chelate in the microgreens industry has not been explored. Compared with fruits and mature green leaves, fresh-cut microgreens are very tender and subject to much more stress, leading to rapid senescence and a very short shelf life (Watkins and Nock, 2012). For example, the shelf life of broccoli microgreens (Brassica oleracea L. var. italica) is $7-10 \mathrm{~d}$ at $5{ }^{\circ} \mathrm{C}$. However, if treated by $10 \mathrm{mmol} \cdot \mathrm{L}^{-1} \mathrm{CaCl}_{2}$ before harvest, the shelf life can be extended to $14-21 \mathrm{~d}$ due to stimulated superoxide dismutase and peroxidase activities, lowered tissue electrolyte leakage, improved overall visual quality, and reduced microbial growth during storage (Kou et al., 2014a). A chemical composition comparison showed that glucosinolates, a very important group of phytochemicals, were the major compounds enhanced by preharvest treatment with $10 \mathrm{mmol} \cdot \mathrm{L}^{-1} \mathrm{CaCl}_{2}$ (Sun et al., 2015). This study compares the effects of preharvest spray with $\mathrm{CaCl}_{2}, \mathrm{Ca}$ lactate, or $\mathrm{Ca} \mathrm{AA}$ chelate, and a postharvest dip in Ca lactate on the quality and shelf life of broccoli microgreens. 


\section{Materials and Methods}

Plant materials. Broccoli (Brassica oleracea var. italica) cultivar Arcadia seeds were purchased from Living Whole Foods, Inc. (Springville, UT). Hydroponic pads $(20.8 \times$ $25.4 \mathrm{~cm}$; Growers Supply, Dyersville, IA) were made from biodegradable wood fibers. One hydroponic pad was set evenly in one $54 \times$ $28 \times 6 \mathrm{~cm}$ tray (vacuum-formed standard 1020 open flats without holes). The pad was soaked in the $600 \mathrm{~mL}$ tap water (pH 5.5-6.0). The seeds $(\approx 37.8 \mathrm{~g})$ were spread evenly on the wet pad. The trays were kept in the dark in a growth chamber at $25^{\circ} \mathrm{C}$ for the first $4 \mathrm{~d}$, and then exposed to light with an irradiance of $42 \mu \mathrm{mol} \cdot \mathrm{s}^{-1} \cdot \mathrm{m}^{-2}$, of $12 \mathrm{~h} / 12 \mathrm{~h}$ (light/dark) for the next $6 \mathrm{~d}$ (Kou et al., 2013).

Preharvest calcium treatments. The trays were sprayed once a day with $\approx 200 \mathrm{~mL} \mathrm{H}_{2} \mathrm{O}$ (tap water, $\mathrm{pH}$ 5.5-6.0) only; 1, 10, or $20 \mathrm{mmol} \cdot \mathrm{L}^{-1} \mathrm{Ca}$ AA (Albion Laboratories, Inc., Clearfield, UT); 1,10 , or $20 \mathrm{mmol} \cdot \mathrm{L}^{-1}$ Ca lactate; or $10 \mathrm{mmol} \cdot \mathrm{L}^{-1} \mathrm{CaCl}_{2}$ (SigmaAldrich, Inc., St. Louis, $\mathrm{MO}$ ) after sowing the seeds (Table 1). Ten-day-old broccoli microgreens were harvested with a pair of sterilized scissors by cutting at the bottom of the hypocotyls. No damaged leaves were used for analyses. The broccoli microgreens (10 g each) were packaged in sealed bags $(10 \mathrm{~cm} \times 10 \mathrm{~cm})$ prepared with polyethylene films (Pacific Southwest Container Inc., Modesto, CA) of $16.6 \mathrm{pmol} \cdot \mathrm{s}^{-1} \cdot \mathrm{m}^{-2} \cdot \mathrm{Pa}^{-1}$ oxygen transmission rate. Samples were stored at $5{ }^{\circ} \mathrm{C}$ in the dark for $21 \mathrm{~d}$, with quality evaluation performed on Days $0,4,7$, 14 , and 21.

Postharvest calcium treatments. Ten-dayold seedlings treated with water-only during preharvest were moved to the washroom across the aisle. Dip solutions contain 0, 25, 50 , or $100 \mathrm{mmol} \cdot \mathrm{L}^{-1} \mathrm{Ca}$ lactate plus $100 \mu \mathrm{L} \cdot \mathrm{L}^{-1}$ chlorine (sodium hypochlorite, $\mathrm{pH}$ 6.5) (Table 1). The freshly cut microgreens $(200 \mathrm{~g})$ were placed in predisinfected mesh bags, washed in $40 \mathrm{~L}$ dip solutions with gentle agitation for $30 \mathrm{~s}$ at room temperature, then centrifuged at $300 \mathrm{rpm}$ for $3 \mathrm{~min}$ with a commercial salad centrifugal dryer (model T-304, Garroute Spin Dryer; Meyer Machine Co, San Antonio, TX) to remove excess water. The washed microgreens were packaged in $10 \mathrm{~g}$ amounts in each bag and stored at $5^{\circ} \mathrm{C}$ in the dark for $14 \mathrm{~d}$. Evaluations were performed on Days 0, 4, 7, 11, and 14 .

Pre-/postharvest calcium treatments. The following combinations of pre- and postharvest calcium treatments were performed (Table 1). $\mathrm{H}_{2} \mathrm{O} / \mathrm{Cl}$ meant preharvest spray with water only and postharvest dip in $100 \mu \mathrm{L} \cdot \mathrm{L}^{-1}$ chlorine solution; $\mathrm{H}_{2} \mathrm{O} / \mathrm{Ca}$ lactate indicated preharvest water spray and postharvest dip in $50 \mathrm{mmol} \cdot \mathrm{L}^{-1} \mathrm{Ca}$ lactate and $100 \mu \mathrm{L} \cdot \mathrm{L}^{-1}$ chlorine solution; $\mathrm{CaCl}_{2} / \mathrm{Cl}$ stood for preharvest $10 \mathrm{mmol} \cdot \mathrm{L}^{-1} \mathrm{CaCl}_{2}$ spray and postharvest dip in $100 \mu \mathrm{L} \cdot \mathrm{L}^{-1}$ chlorine solution; $\mathrm{CaCl}_{2} / \mathrm{Ca}$ lactate represented preharvest $10 \mathrm{mmol} \cdot \mathrm{L}^{-1} \mathrm{CaCl}_{2}$ spray and postharvest dip in $50 \mathrm{mmol} \cdot \mathrm{L}^{-1} \mathrm{Ca}$ lactate with $100 \mu \mathrm{L} \cdot \mathrm{L}^{-1}$ chlorine solution. Microgreens (200 g) were

Table 1. List of all the treatments.

\begin{tabular}{|c|c|c|c|}
\hline Treatment & & Preharvest spray & $\begin{array}{l}\text { Postharvest dip in } \\
\text { chlorinated water }\end{array}$ \\
\hline Preharvest treatment & & $\begin{array}{l}\text { Water only } \\
10 \mathrm{mmol} \cdot \mathrm{L}^{-1} \mathrm{CaCl}_{2} \\
1 \mathrm{mmol} \cdot \mathrm{L}^{-1} \mathrm{Ca} \text { lactate } \\
10 \mathrm{mmol} \cdot \mathrm{L}^{-1} \mathrm{Ca} \text { lactate } \\
20 \mathrm{mmol} \cdot \mathrm{L}^{-1} \mathrm{Ca} \text { lactate } \\
1 \mathrm{mmol} \cdot \mathrm{L}^{-1} \mathrm{Ca} \text { AA } \\
10 \mathrm{mmol} \cdot \mathrm{L}^{-1} \mathrm{Ca} \mathrm{AA} \\
20 \mathrm{mmol} \cdot \mathrm{L}^{-1} \mathrm{Ca} \mathrm{AA}\end{array}$ & No postharvest dip \\
\hline Postharvest treatment & & Water only & $\begin{array}{l}\text { No calcium } \\
25 \mathrm{mmol} \cdot \mathrm{L}^{-1} \mathrm{Ca} \text { lactate } \\
50 \mathrm{mmol} \cdot \mathrm{L}^{-1} \mathrm{Ca} \text { lactate } \\
100 \mathrm{mmol} \cdot \mathrm{L}^{-1} \mathrm{Ca} \text { lactate }\end{array}$ \\
\hline Pre/postharvest treatment & $\begin{array}{l}\mathrm{H}_{2} \mathrm{O} / \mathrm{Cl} \\
\mathrm{H}_{2} \mathrm{O} / \mathrm{Ca} \text { lactate } \\
\mathrm{CaCl}_{2} / \mathrm{Cl} \\
\mathrm{H}_{2} \mathrm{O} / \mathrm{Ca} \text { lactate } \\
\end{array}$ & $\begin{array}{l}\text { Water only } \\
10 \mathrm{mmol} \cdot \mathrm{L}^{-1} \mathrm{CaCl}_{2}\end{array}$ & $\begin{array}{l}\text { No calcium } \\
50 \mathrm{mmol} \cdot \mathrm{L}^{-1} \mathrm{Ca} \text { lactate } \\
\text { No calcium } \\
50 \mathrm{mmol} \cdot \mathrm{L}^{-1} \mathrm{Ca} \text { lactate }\end{array}$ \\
\hline
\end{tabular}

$\mathrm{CaCl}_{2}=$ calcium chloride; $\mathrm{Ca}$ lactate $=$ calcium calculate Ca $\mathrm{AA}=$ calcium amino acid.

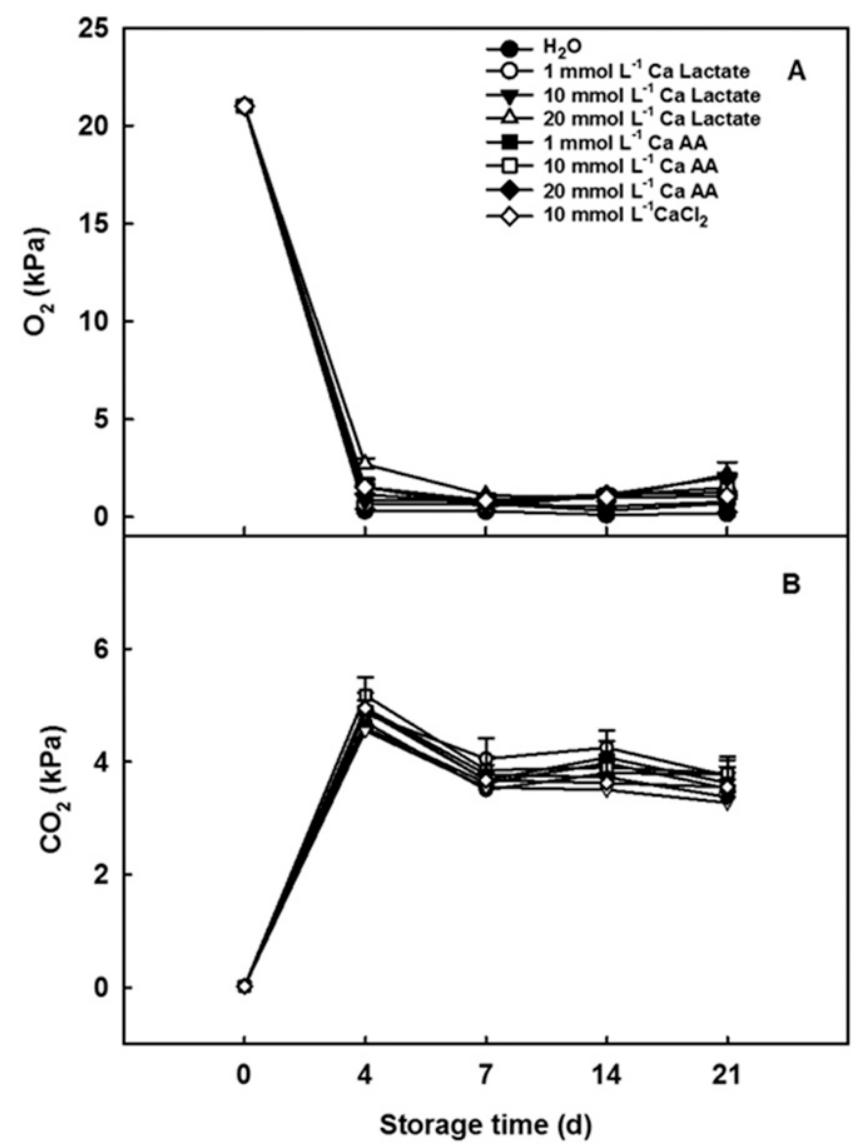

Fig. 1. Effects of preharvest spray with different calcium forms on (A) $\mathrm{O}_{2}$ and (B) $\mathrm{CO}_{2}$ partial pressure within packages of broccoli microgreens during $5{ }^{\circ} \mathrm{C}$ storage. Data presented are the means of four replications; vertical lines represent SES.

placed in mesh bags, and then washed in $40 \mathrm{~L}$ wash solutions with gentle agitation for $30 \mathrm{~s}$. The microgreens (in mesh bags) were centrifuged at $300 \mathrm{rpm}$ for $3 \mathrm{~min}$ with a commercial salad centrifugal dryer (model T-304, Garroute Spin Dryer; Meyer Machine $\mathrm{Co}$ ) to remove excess water. The washed microgreens were packaged in $10 \mathrm{~g}$ amounts in each bag. Packaged microgreens were stored at $5{ }^{\circ} \mathrm{C}$ in the dark for $14 \mathrm{~d}$ and evaluations were performed on Days $0,4,7$, 11 , and 14.
Postharvest quality and microbiological assessment. The package atmospheres were measured immediately upon removal of the samples from storage. The $\mathrm{CO}_{2}$ and $\mathrm{O}_{2}$ in the headspace of packages containing microgreens were measured as described in Kou et al. (2014a).

Overall visual quality was evaluated with a 9-point hedonic scale following a modified procedure from Luo et al. (2004) and Meilgaard et al. (1991), where 9, 8, 7, and $6=$ like extremely, strongly, moderately, and slightly, 
respectively; $5=$ neither like nor dislike; and 1 , 2,3 , and $4=$ dislike extremely, strongly, moderately, and slightly, respectively. All visual quality evaluations were carried out by three trained evaluators. All evaluators had over 5-year research experience with fresh produce, especially performing sensory evaluations of leafy greens. Before the beginning of this experiment, additional training specific to the organoleptic properties of broccoli microgreens were provided to evaluators. The acceptable range for overall visual quality was considered to be a score of 6.0 or above (Kou et al., 2014b).

The electrical conductivity of the solution was measured using the same method as described in Kou et al. (2014a). Briefly, 3 g microgreens were submerged in $150 \mathrm{~mL}$ deionized water at $20{ }^{\circ} \mathrm{C}$ and shaken for 30 min. The electrolyte of the solution was measured using a conductivity meter (model 135A; Orion Research, Inc., Beverly, MA). Total electrolytes were obtained after freezing the samples at $-20{ }^{\circ} \mathrm{C}$ for $24 \mathrm{~h}$ and subsequent thawing, and expressed as a percentage of the total electrolyte. Microbial growth on broccoli microgreens was assayed following a procedure from Luo et al. (2004) with some modifications. Each $3 \mathrm{~g}$ microgreens was macerated in $27 \mathrm{~mL}$ phosphatebuffered saline, using a model 80 Laboratory Stomacher (Seward Medical, London, UK) for $2 \mathrm{~min}$ at high speed in filtered stomacher bags. A $50 \mu \mathrm{L}$ sample of each filtrate or its appropriate dilution was logarithmically spread on agar plates with an automated spiral plater (Wasp II; Don Whitley Scientific Ltd., West Yorkshire, UK). Enumeration of microorganisms was performed using the following culture media and conditions: 1) tryptic soy agar (Difco Laboratory, Sparks, MD) incubated at $28{ }^{\circ} \mathrm{C}$ for $24 \mathrm{~h}$ for the enumeration of total aerobic mesophilic bacteria (AMB) and 2) potato dextrose agar (Difco Laboratory) supplemented with $200 \mathrm{~g} \cdot \mathrm{mL}^{-1}$ chloramphenicol incubated at room temperature $\left(22^{\circ} \mathrm{C}\right)$ for $48 \mathrm{~h}$ for the enumeration of yeasts and molds (Y\&M). Microbial colonies were counted using a ProtoCOL Colony Counter 50000 (Synoptics, Cambridge, UK) and reported as Log cfu/g (Log colony-forming unit per gram tissue).

Experimental design and statistical analysis. Package atmospheres, tissue electrolyte leakage, and microbial data were analyzed as two-factor linear models using the PROC MIXED procedure (SAS Institute Inc., 1999, Cary, NC). The two factors were storage time and treatment type. Different samples were analyzed on each evaluation day for all studies. Four replications (four bags) per treatment per evaluation period were examined. All the experiments were repeated three times. At each time, we had four technical repeats. Data presented are the results from one representative experiment. Assumptions of normality and variance homogeneity of the linear model were checked and the variance grouping technique was used to correct for variance heterogeneity. When effects were statistically significant, means were compared using Sidak adjusted $P$ values to maintain experiment-wise error $\leq 0.05$.

\section{Results and Discussion}

Effects of different preharvest calcium treatments on the postharvest quality of broccoli microgreens. From Day 0 to 4, oxygen partial pressures in all the samples decreased rapidly (Fig. 1A), nearly reaching equilibrium by Day 4 . Water-only control exhibited the lowest $\mathrm{O}_{2}$ level from Day 4 to 21. All the calcium treatments had a slightly higher yet constant $\mathrm{O}_{2}(1-2.2 \mathrm{kPa})$ until the end of storage. In comparison, $\mathrm{CO}_{2}$ partial pressure for all treatments increased during the first $4 \mathrm{~d}$, and then declined to $\approx 3.7 \mathrm{kPa}$. No significant difference was observed among all the calcium treatments and water-only control (Fig. 1B). These results suggest that the preharvest calcium treatments had no significant effect on broccoli microgreens' respiration during cold storage. Other studies also show that under low temperature storage, calcium treatment did not affect the respiration rate on lettuce, carrot, 'Vogue' cherry, and apple (Duque and Arrabaça, 1999; Martín-Diana et al., 2005; Tsantili et al., 2007).

Total AMB growth of all samples increased significantly $(P<0.001)$ over storage time (Fig. 2A). However, on Day 21, the numbers of total AMB in calcium treatments were lower than water-only control. In particular, $10 \mathrm{mmol} \cdot \mathrm{L}^{-1} \mathrm{CaCl}_{2}$-treated samples had significantly $(P<0.05)$ lower total AMB (8.9 Log cfu/g) growth than those sprayed with $\mathrm{H}_{2} \mathrm{O}(9.9 \mathrm{Log} \mathrm{cfu} / \mathrm{g})$ at Day 21 . Nonetheless, no significant $(P>0.05)$ difference was found among all other calcium treatments. Several calcium treatments also displayed significantly inhibitory effect on Y\&M growth (Fig. 2B). Among these treatments, $10 \mathrm{mmol} \cdot \mathrm{L}^{-1} \mathrm{CaCl}_{2}$ treatment was the most effective. On Day 21, $10 \mathrm{mmol} \cdot \mathrm{L}^{-1}$ $\mathrm{CaCl}_{2}$-treated samples averaged $1.2 \mathrm{Log}$ $\mathrm{cfu} / \mathrm{g}(P<0.05)$ fewer Y\&M colonies than the water-only treatment. 1 and $20 \mathrm{~mm} \mathrm{Ca}$ lactate also had obvious inhibitory effect at Day 21.

We further measured tissue electrolyte leakage because it was closely related to the tissue integrity and shelf life of fresh-cut produce (Allende et al., 2004; Kou et al., 2013). All the calcium-treated samples had lower tissue electrolyte leakage $(P<0.05)$ than water-only control samples during the entire storage period (Fig. 3A). Samples treated with higher calcium concentrations had significant lower tissue electrolyte leakage than those treated with low concentration $\left(1 \mathrm{mmol} \cdot \mathrm{L}^{-1}\right)$. At Day 21 , the highest tissue electrolyte leakage $(18.75 \%)$ occurred in water-only treated samples, whereas $10 \mathrm{mmol} \cdot \mathrm{L}^{-1} \mathrm{CaCl}_{2}$ treatment had the lowest tissue electrolyte leakage values of $3.56 \%$. Tissue electrolyte leakage in $20 \mathrm{mmol} \cdot \mathrm{L}^{-1} \mathrm{Ca}$ lactate, $10 \mathrm{mmol} \cdot \mathrm{L}^{-1} \mathrm{Ca}$ lactate, $20 \mathrm{mmol} \cdot \mathrm{L}^{-1}$ $\mathrm{Ca} \mathrm{AA}$ and $10 \mathrm{mmol} \cdot \mathrm{L}^{-1} \mathrm{Ca}$ AA were $3.97 \%$, $4.00 \%, 4.02 \%$, and $10.4 \%$, respectively. Calcium application has shown to increase membrane integrity and stability, and decrease electrolyte leakage (Esmel et al., 2004; Poovaiah, 1986). Calcium may also be involved in regulating membrane stability and the senescence of plant cells (Rubinstein, 2000; Torre et al., 1999). Less disruption in plasma membranes led to lower tissue electrolyte leakage (Meng et al., 2009). Therefore, preharvest calcium spray might increase broccoli membrane integrity and reduce tissue electrolyte leakage.

Overall quality is an important factor influencing the marketability of food products. All calcium-treated samples retained superior quality over water-treated samples from Day 7 onwards (Fig. 3B). From Day 14 onwards, yellowing leaves and moisture accumulation were observed on broccoli microgreens, which resulted in reduced quality scores. On Day 21, the overall quality scores in all calcium-treated samples declined to 5.2-6.3. The $10 \mathrm{mmol} \cdot \mathrm{L}^{-1} \quad \mathrm{CaCl}_{2}$-treated samples had the highest overall visual quality, especially from Day 14 to 21. On Day 21, $20 \mathrm{mmol} \cdot \mathrm{L}^{-1} \mathrm{Ca}$ lactate also maintained a better overall quality score (scores of 5.7), while water-treated seedlings had the lowest overall quality (score of 2.9). The results indicated that the preharvest treatment with all three forms of calcium had a positive effect on postharvest quality and prolonged shelf life of microgreens. The overall quality results agreed well with those from tissue electrolyte leakage, suggesting that the loss of visual appeal was related to senescence.

Effect of postharvest calcium lactate wash/ dip on the quality of broccoli microgreens. Since preharvest treatment with $\mathrm{Ca}$ AA was least effective, we only selected Ca lactate for postharvest treatments. After dipping, spinning, and drying, the shelf life for all samples was reduced to $14 \mathrm{~d}$ from $21 \mathrm{~d}$. This could have been resulted from the tissue physical damage to the tissue during spinning and drying because the microgreens were very tender. During the first 3 days of storage after treatments, the headspace $\mathrm{O}_{2}$ concentration of all the samples dropped rapidly to under 1 $\mathrm{kPa}$, and slowly dropped to near 0 at the end of storage (Fig. 4A). However, the $\mathrm{CO}_{2}$ level increased rapidly during the first $3 \mathrm{~d}$, followed by a rapid decrease, then maintained a constant level $(\approx 4 \mathrm{kPa})$ of $\mathrm{CO}_{2}$ (Fig. 4B). No significant differences were observed between the dip in $\mathrm{Ca}$ lactate and dip in chlorinated water only. These results suggest that postharvest calcium treatment had no significant effect on $\mathrm{O}_{2}$ depletion and $\mathrm{CO}_{2}$ evolution rates for broccoli microgreens.

Significant $(P<0.05)$ differences were detected among dip treatments with different $\mathrm{Ca}$ lactate concentrations for tissue electrolyte leakage and overall quality (Fig. 5A and B). Broccoli microgreens treated with $50 \mathrm{mmol} \cdot \mathrm{L}^{-1}$ Ca lactate maintained the lowest tissue electrolyte leakage $(4.2 \%)$ throughout the 14-day storage period and had the highest overall quality score (6.0) on Day 14. Water-treated samples had significantly $(P<0.01)$ higher tissue electrolyte leakage and lower overall quality than all calcium treated ones. These 


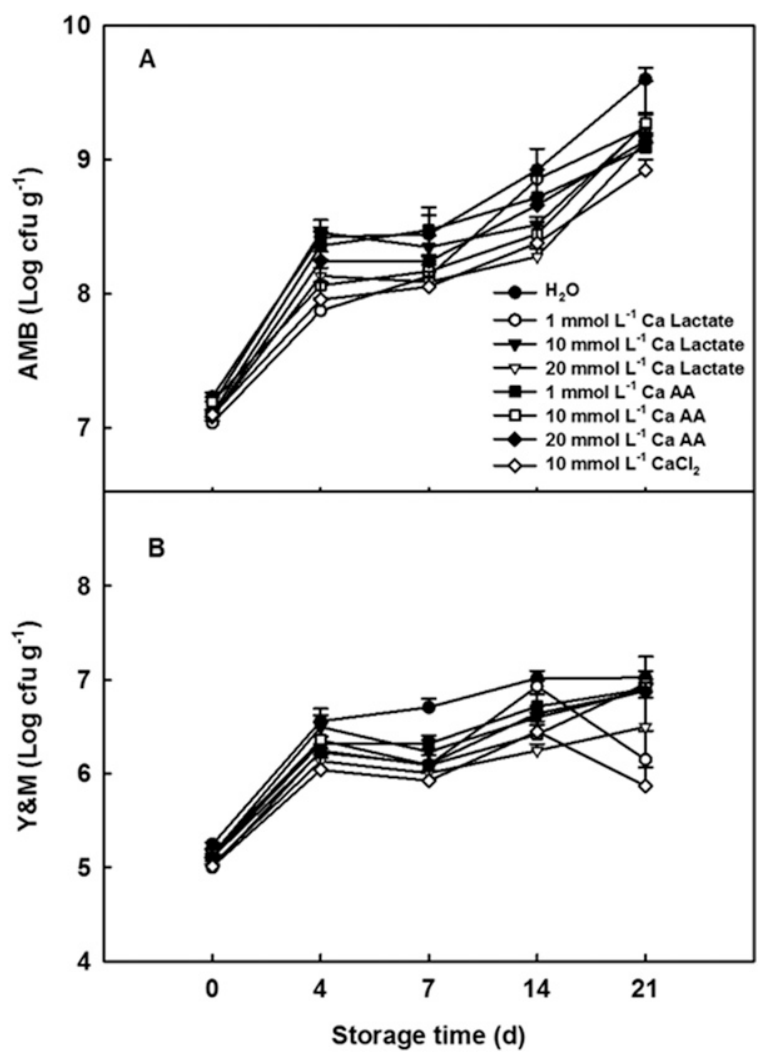

Fig. 2. Effects of preharvest spray with different calcium forms on (A) aerobic mesophilic bacteria (AMB) and (B) yeast and mold (Y\&M) populations of packaged broccoli microgreens during $5{ }^{\circ} \mathrm{C}$ storage. Data presented are the means of four replications; vertical lines represent SES.

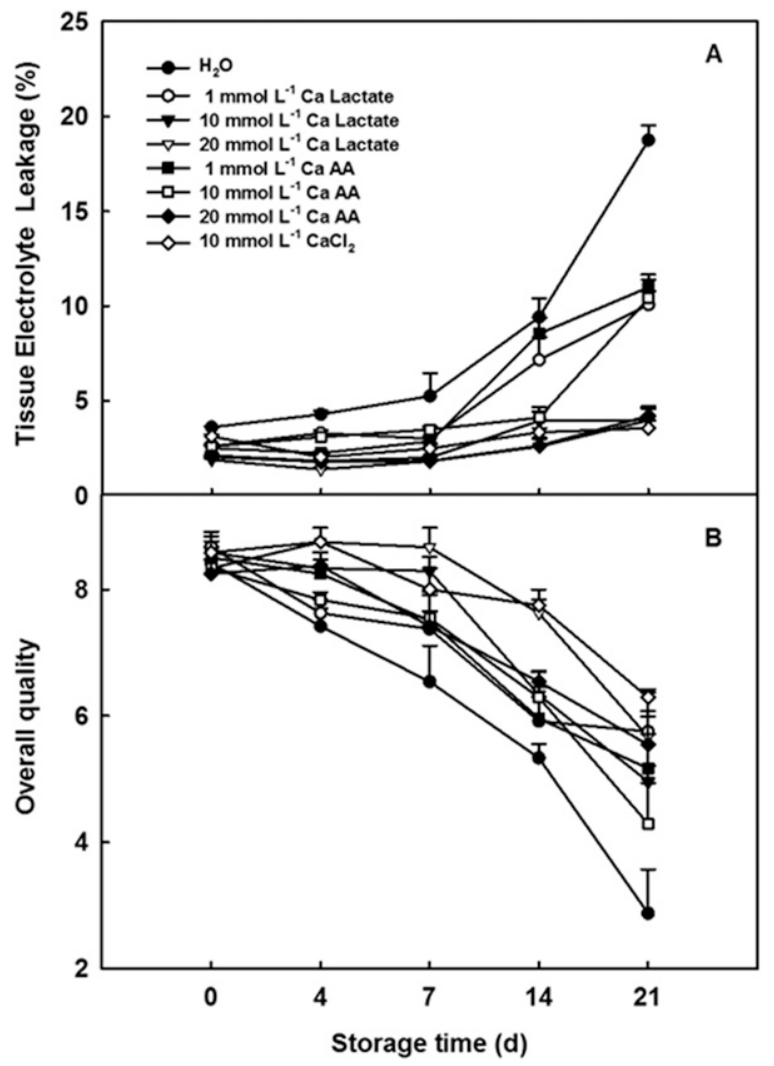

Fig. 3. Effects of preharvest spray with different calcium forms on (A) tissue electrolyte leakage and (B) overall quality of packaged broccoli microgreens during $5{ }^{\circ} \mathrm{C}$ storage. Data presented are the means of four replications; vertical lines represent SES. results suggest that $25 \mathrm{mmol} \cdot \mathrm{L}^{-1}$ is insufficient to act and $100 \mathrm{mmol} \cdot \mathrm{L}^{-1}$ is likely toxic for microgreens. Fifty $\mathrm{mmol} \cdot \mathrm{L}^{-1} \mathrm{Ca}$ lactate dip had a positive effect on extending the shelf life and keeping the lower tissue electrolyte leakage. However, in general, the spinning and drying after dip dramatically accelerated tissue senescence and quality deterioration.

Effect of combined pre-/postharvest calcium treatment on the quality of broccoli microgreens. We further tested the effect of combining preharvest $10 \mathrm{mmol} \cdot \mathrm{L}^{-1} \mathrm{CaCl}_{2}$ and postharvest $50 \mathrm{mmol} \cdot \mathrm{L}^{-1} \mathrm{Ca}$ lactate treatments on the quality of microgreens. During the entire 14-day storage period, no significant differences were found in the changes in $\mathrm{O}_{2}$ and $\mathrm{CO}_{2}$ composition in packages between any of the treatments (Fig. 6A and B). These results were in agreement with those observed for the separate pre- and postharvest calcium treatments (Figs. 1 and 4).

AMB populations for all the treatments increased significantly $(P<0.001)$ during storage (Fig. 7A). Overall, there was no significant difference between any of the different $\mathrm{H}_{2} \mathrm{O}$ or calcium dip treatments. In comparison, samples with preharvest $\mathrm{CaCl}_{2}$ spray but no postharvest treatment had significantly $(P<0.01)$ lower bacterial populations than those receiving other pre-/postharvest treatments. These results suggest that the increased bacterial populations resulted from the tissue damage and/or contamination during postharvest dip.

Similar to AMB populations, Y\&M populations had an increasing trend during the storage (Fig. 7B). From Day 0 to 7 , Y\&M populations maintained stable levels (5.2-6.0 $\log \mathrm{cfu} / \mathrm{g}$ ). However, from Day 7 to 14 , there was a rapid increase in $Y \& M$ populations for all the treatments. The preharvest treatments with $\mathrm{CaCl}_{2}$ without postharvest treatment had significantly $(P<0.01)$ lower Y\&M populations than all other combinations of pre/ postharvest calcium treatments. Lee et al. (2009) reported a similar result for 'Tah tasai' Chinese cabbage microgreens treated with chlorinated water. To reduce tissue damage, a slow spin speed was used to dry microgreens. However, excess moisture remaining on washed leaf surfaces might promote microbial growth in those packages.

There was no significant difference for tissue electrolyte leakage among all treatments except, from Day 11 onwards, tissue electrolyte leakage for $\mathrm{H}_{2} \mathrm{O} / \mathrm{Cl}$ treatment was significantly higher $(P<0.001)$ than that of other treatments and remained higher $(P<$ 0.01 ) through the end of storage (Fig. 8A). Overall quality for all the pre- and postharvest combined treatments declined significantly $(P<0.05)$ during storage (Fig. 8B). However, preharvest $\mathrm{CaCl}_{2}$ without postharvest dip maintained the highest overall quality score and the lowest tissue electrolyte leakage during the entire $14 \mathrm{~d}$ storage. In contrast, $\mathrm{H}_{2} \mathrm{O} / \mathrm{Cl}$ had the lowest quality score. These results suggest that preharvest calcium spray is more efficient than postharvest dip. There were a few factors influencing the results. 


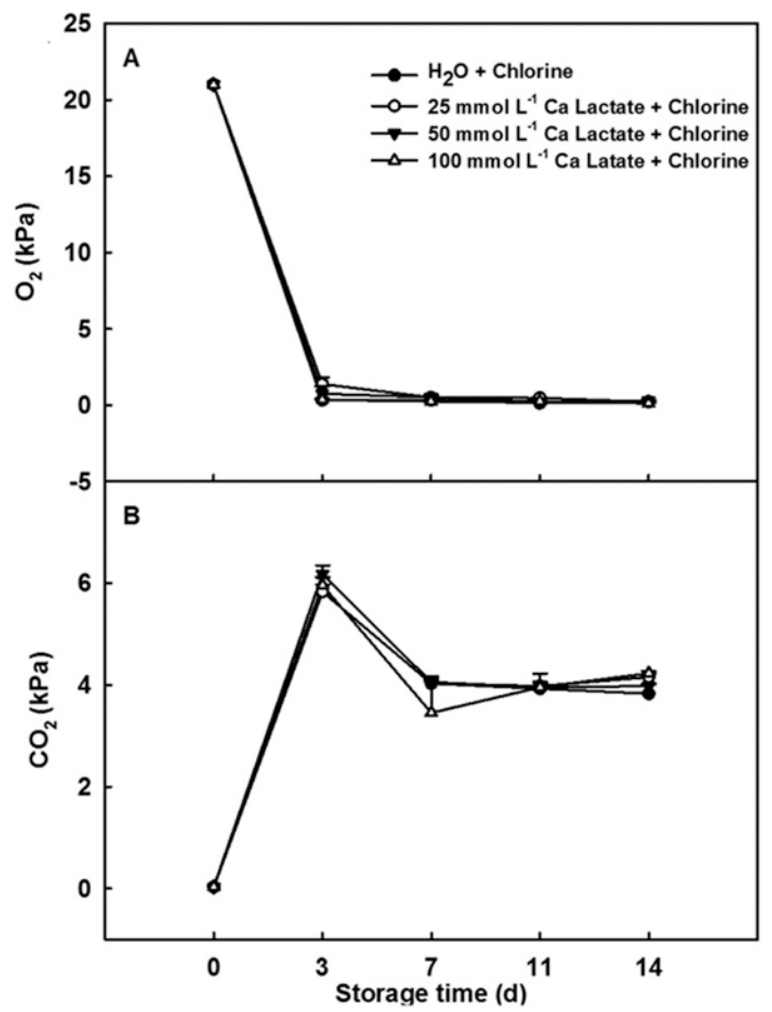

Fig. 4. Effects of postharvest treatment with calcium lactate (Ca lactate) on $(\mathbf{A}) \mathrm{O}_{2}$ and $(\mathbf{B}) \mathrm{CO}_{2}$ partial pressure within packages of broccoli microgreens during $5{ }^{\circ} \mathrm{C}$ storage. $\mathrm{H}_{2} \mathrm{O} / \mathrm{H}_{2} \mathrm{O}+$ chlorine: preharvest water only and postharvest with $100 \mu \mathrm{L} \cdot \mathrm{L}^{-1}$ chlorine; $\mathrm{H}_{2} \mathrm{O} / 25 \mathrm{mmol} \cdot \mathrm{L}^{-1} \mathrm{Ca}$ lactate + chlorine: preharvest water only and postharvest with $25 \mathrm{mmol} \cdot \mathrm{L}^{-1} \mathrm{Ca}$ lactate $+100 \mu \mathrm{L} \cdot \mathrm{L}^{-1}$ chlorine; $\mathrm{H}_{2} \mathrm{O} / 50 \mathrm{mmol} \cdot \mathrm{L}^{-1} \mathrm{Ca}$ lactate + chlorine: preharvest water only and postharvest with $50 \mathrm{mmol} \cdot \mathrm{L}^{-1} \mathrm{Ca}$ lactate $+100 \mu \mathrm{L} \cdot \mathrm{L}^{-1}$ chlorine; $\mathrm{H}_{2} \mathrm{O} / 100 \mathrm{mmol} \cdot \mathrm{L}^{-1} \mathrm{Ca}$ lactate + chlorine: preharvest water only and postharvest with $100 \mathrm{mmol} \cdot \mathrm{L}^{-1} \mathrm{Ca}$ lactate $+100 \mu \mathrm{L} \cdot \mathrm{L}^{-1}$ chlorine; $\mathrm{H}_{2} \mathrm{O} /$ no dip: preharvest water only and no postharvest dip. Data presented are the means of four replications; vertical lines represent SES.

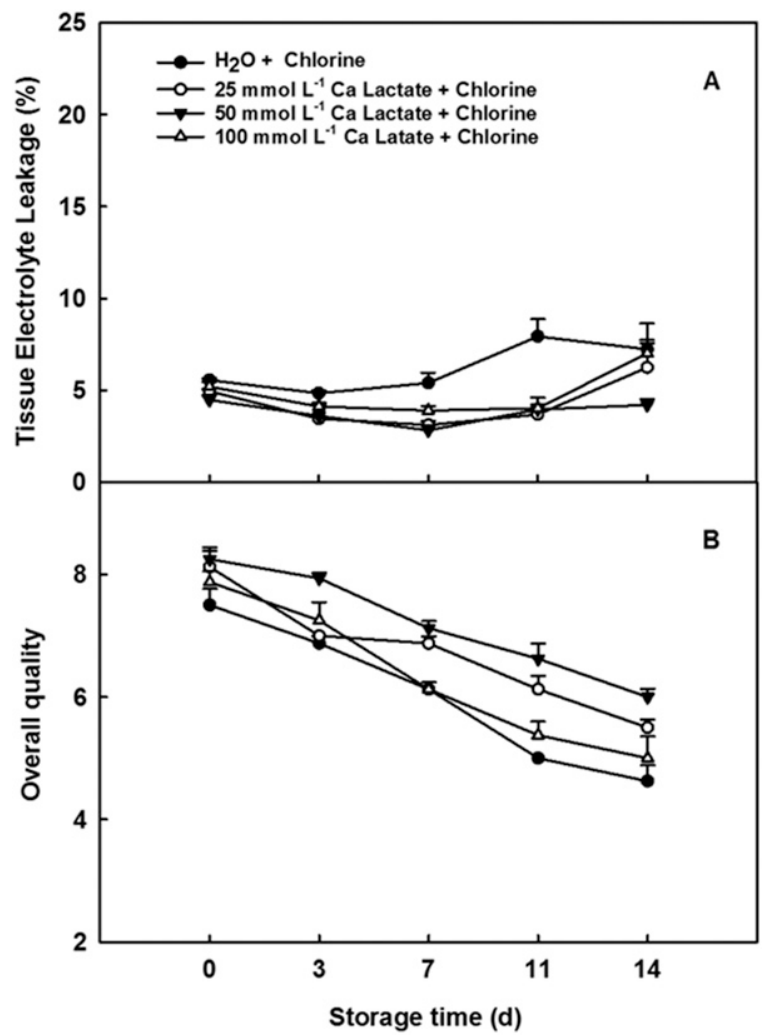

Fig. 5. Effects of postharvest treatment with calcium lactate (Ca lactate) on (A) tissue electrolyte leakage and (B) overall quality of packaged broccoli microgreens during $5{ }^{\circ} \mathrm{C}$ storage. $\mathrm{H}_{2} \mathrm{O} / \mathrm{H}_{2} \mathrm{O}+$ chlorine: preharvest water only and postharvest with $100 \mu \mathrm{L} \cdot \mathrm{L}^{-1}$ chlorine; $\mathrm{H}_{2} \mathrm{O} / 25 \mathrm{mmol} \cdot \mathrm{L}^{-1}$ Ca lactate + chlorine: preharvest water only and postharvest with $25 \mathrm{mmol} \cdot \mathrm{L}^{-1} \mathrm{Ca}$ lactate $+100 \mu \mathrm{L} \cdot \mathrm{L}^{-1}$ sodium hypochlorite; $\mathrm{H}_{2} \mathrm{O} / 50 \mathrm{mmol} \cdot \mathrm{L}^{-1} \mathrm{Ca}$ lactate + chlorine: preharvest water only and postharvest with $50 \mathrm{mmol} \cdot \mathrm{L}^{-1} \mathrm{Ca}$ lactate $+100 \mu \mathrm{L} \cdot \mathrm{L}^{-1}$ chlorine; $\mathrm{H}_{2} \mathrm{O} / 100 \mathrm{mmol} \cdot \mathrm{L}^{-1} \mathrm{Ca}$ lactate + chlorine: preharvest water only and postharvest with $100 \mathrm{mmol} \cdot \mathrm{L}^{-1} \mathrm{Ca}$ lactate $+100 \mu \mathrm{L} \cdot \mathrm{L}^{-1}$ chlorine; $\mathrm{H}_{2} \mathrm{O}$ /no dip: preharvest water only and no postharvest dip. Data presented are the means of four replications; vertical lines represent SES. 


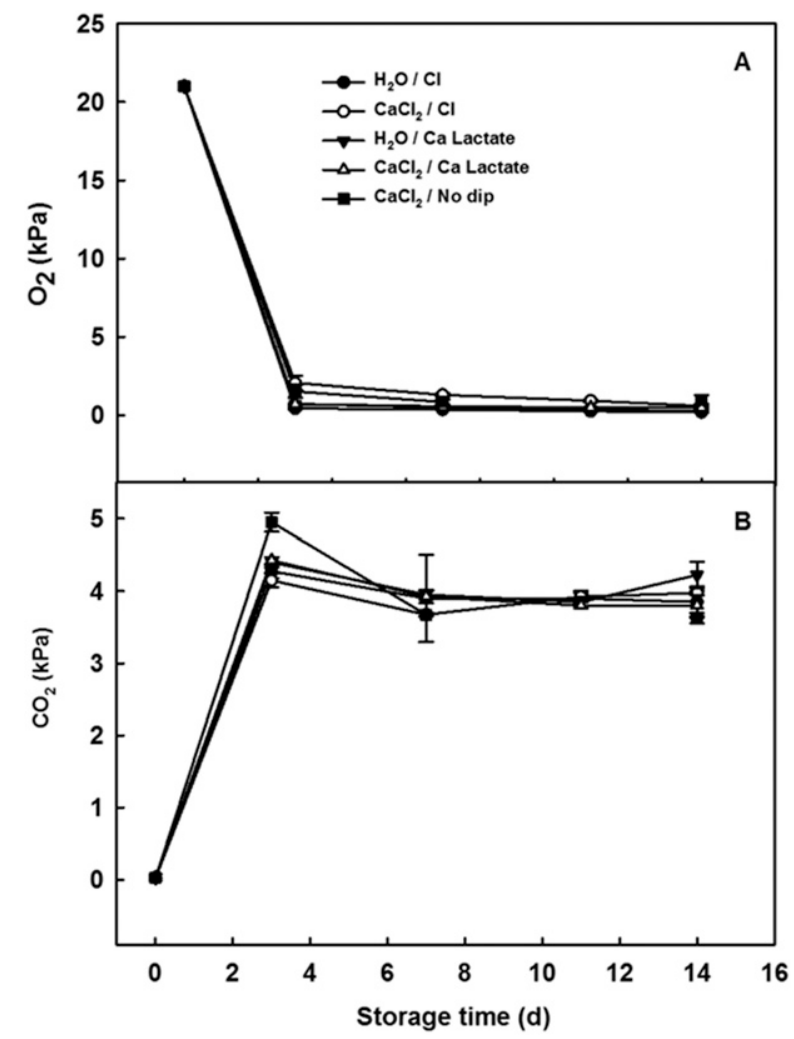

Fig. 6. Effects of combinations of pre/postharvest calcium treatments on $(\mathbf{A}) \mathrm{O}_{2}$ and $(\mathbf{B}) \mathrm{CO}_{2}$ partial pressure within packages of broccoli microgreens during $5{ }^{\circ} \mathrm{C}$ storage. $\mathrm{H}_{2} \mathrm{O} / \mathrm{Cl}$ : preharvest spray with wateronly and postharvest dip in $100 \mu \mathrm{L} \cdot \mathrm{L}^{-1}$ chlorine $(\mathrm{pH} 6.5)$ solution; $\mathrm{H}_{2} \mathrm{O} /$ calcium lactate $(\mathrm{Ca}$ lactate): preharvest water spray only and postharvest dip in $50 \mathrm{mmol} \cdot \mathrm{L}^{-1} \mathrm{Ca}$ lactate plus $100 \mu \mathrm{L} \cdot \mathrm{L}^{-1}$ chlorine; $\mathrm{CaCl}_{2} / \mathrm{Cl}$ : preharvest $10 \mathrm{mmol} \cdot \mathrm{L}^{-1} \mathrm{CaCl}_{2}$ spray and postharvest dip in $100 \mu \mathrm{L} \cdot \mathrm{L}^{-1}$ chlorine; $\mathrm{CaCl}_{2} / \mathrm{Ca}$ lactate: preharvest $10 \mathrm{mmol} \cdot \mathrm{L}^{-1} \mathrm{CaCl}_{2}$ spray and postharvest dip in $50 \mathrm{mmol} \cdot \mathrm{L}^{-1} \mathrm{Ca}$ lactate plus $100 \mu \mathrm{L} \cdot \mathrm{L}^{-1} \mathrm{chlorine} ; \mathrm{CaCl} / \mathrm{no}$ dip: preharvest $10 \mathrm{mmol} \cdot \mathrm{L}^{-1} \mathrm{CaCl}_{2}$ and no postharvest dip. Data presented are the means of four replications; vertical lines represent SES.

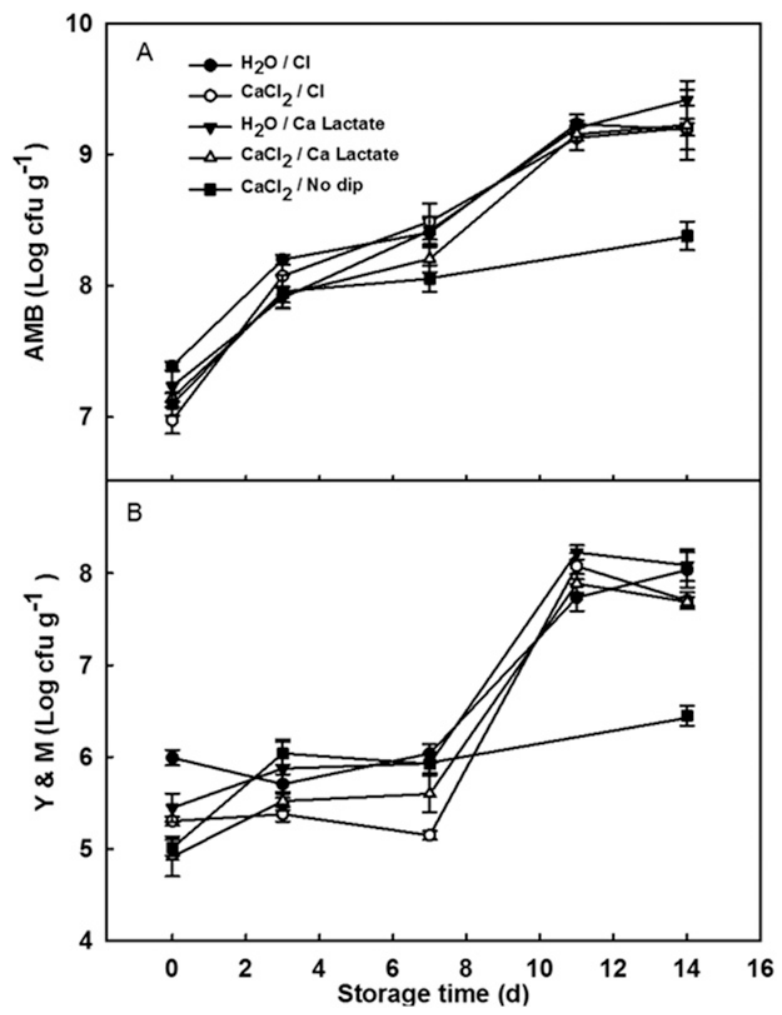

Fig. 7. Effects of combinations of pre/postharvest calcium treatments on (A) aerobic mesophilic bacteria (AMB) and (B) yeast and mold (Y\&M) populations of packaged broccoli microgreens during $5^{\circ} \mathrm{C}$ storage. $\mathrm{H}_{2} \mathrm{O} / \mathrm{Cl}$ : preharvest spray with water only and postharvest dip in $100 \mu \mathrm{L} \cdot \mathrm{L}^{-1}$ chlorine $(\mathrm{pH} 6.5)$ solution; $\mathrm{H}_{2} \mathrm{O} /$ calcium lactate (Ca lactate): preharvest water spray only and postharvest dip in $50 \mathrm{mmol} \cdot \mathrm{L}^{-1} \mathrm{Ca}$ lactate plus $100 \mu \mathrm{L} \cdot \mathrm{L}^{-1}$ chlorine; $\mathrm{CaCl}_{2} / \mathrm{Cl}_{\text {: preharvest } 10 \mathrm{mmol} \cdot \mathrm{L}^{-1} \mathrm{CaCl}}$ spray and postharvest dip in $100 \mu \mathrm{L} \cdot \mathrm{L}^{-1}$ chlorine; $\mathrm{CaCl}_{2} / \mathrm{Ca}$ lactate: preharvest $10 \mathrm{mmol} \cdot \mathrm{L}^{-1} \mathrm{CaCl}_{2}$ spray and postharvest dip in $50 \mathrm{mmol} \cdot \mathrm{L}^{-1} \mathrm{Ca}$ lactate plus $100 \mu \mathrm{L} \cdot \mathrm{L}^{-1}$ chlorine; $\mathrm{CaCl}_{2} /$ no dip: preharvest $10 \mathrm{mmol} \cdot \mathrm{L}^{-1} \mathrm{CaCl}_{2}$ and no postharvest dip. Data presented are the means of four replications; vertical lines represent sEs. 


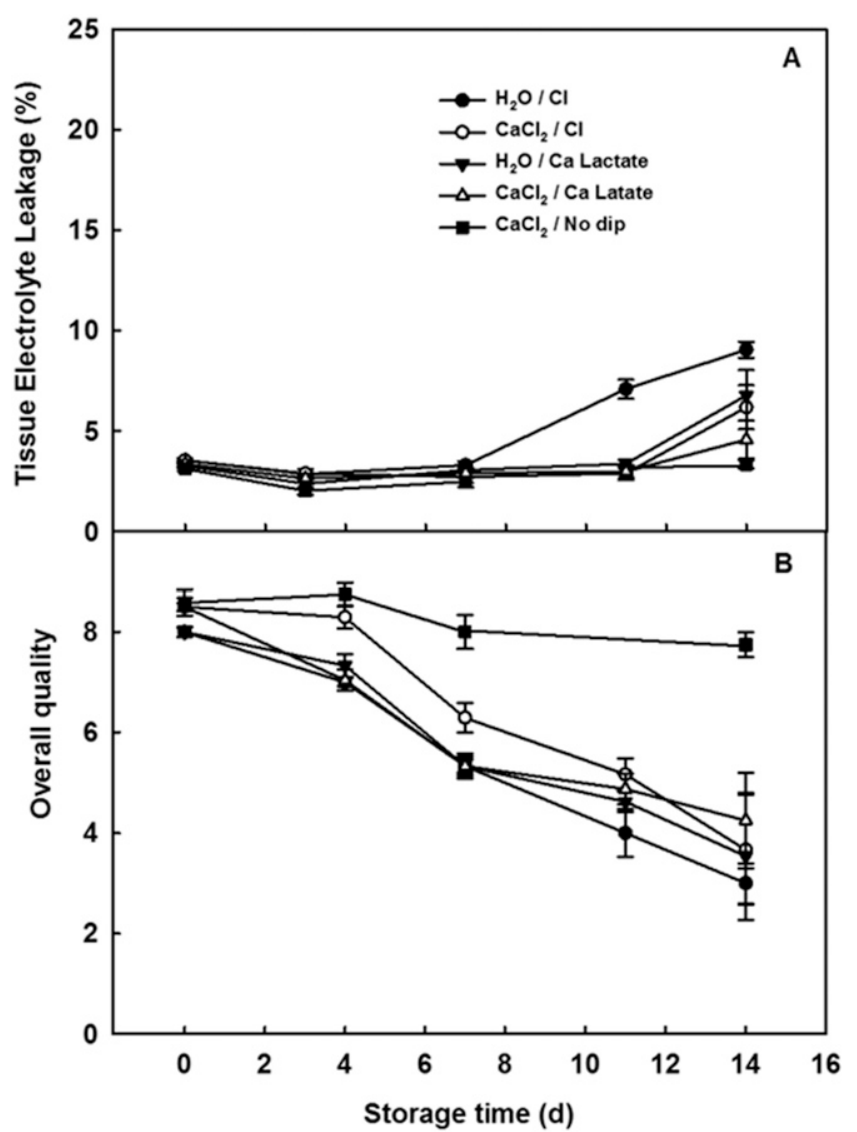

Fig. 8. Effects of combinations of pre/postharvest calcium treatments on (A) tissue electrolyte leakage and (B) overall quality of packaged broccoli microgreens during $5{ }^{\circ} \mathrm{C}$ storage. $\mathrm{H}_{2} \mathrm{O} / \mathrm{Cl}$ : preharvest spray with water only and postharvest dip in $100 \mu \mathrm{L} \cdot \mathrm{L}^{-1}$ chlorine $\left(\mathrm{pH}\right.$ 6.5) solution; $\mathrm{H}_{2} \mathrm{O}$ /calcium lactate $(\mathrm{Ca}$ lactate): preharvest water spray only and postharvest dip in $50 \mathrm{mmol} \cdot \mathrm{L}^{-1} \mathrm{Ca}$ lactate plus $100 \mu \mathrm{L} \cdot \mathrm{L}^{-1}$ chlorine; $\mathrm{CaCl}_{2} / \mathrm{Cl}$ : preharvest $10 \mathrm{mmol} \cdot \mathrm{L}^{-1} \mathrm{CaCl}_{2}$ spray and postharvest dip in $100 \mu \mathrm{L} \cdot \mathrm{L}^{-1}$ chlorine; $\mathrm{CaCl}_{2} / \mathrm{Ca}$ lactate: preharvest $10 \mathrm{mmol} \cdot \mathrm{L}^{-1} \mathrm{CaCl}_{2}$ spray and postharvest dip in $50 \mathrm{mmol} \cdot \mathrm{L}^{-1} \mathrm{Ca}$ lactate plus $100 \mu \mathrm{L} \cdot \mathrm{L}^{-1}$ chlorine; $\mathrm{CaCl}_{2} /$ no dip: preharvest $10 \mathrm{mmol} \cdot \mathrm{L}^{-1} \mathrm{CaCl}_{2}$ and no postharvest dip. Data presented are the means of four replications; vertical lines represent SES.

First, calcium solution was sprayed every day during preharvest treatment. However, postharvest calcium treatment consisted of only a $30 \mathrm{~s}$ dip. Second, postharvest dip was applied just before packaging and extra moisture on the surface was not easily removed without resulting in dehydration and or additional tissue damage to the already cut tissues. Third, spinning and drying processes caused tissue injury which might accelerate quality deterioration and encourage microbial growth. On buckwheat microgreens, we also found that unwashed samples maintained better visual quality and lower tissue electrolyte leakage than washed samples (Kou et al., 2013). Therefore, the spinning and drying steps were the major factors to reduce the microgreen postharvest quality. In order for processors to be able to provide safe ready-toeat products, improved wash and drying technologies for microgreens need to be developed.

\section{Conclusions}

In this study, the effects of various pre/ postharvest calcium treatments on the quality and shelf life of broccoli microgreens materials used for propagation can be easily decontaminated to maintain compliance with food safety regulations.

\section{Literature Cited}

Allende, A., Y. Luo, J. McEvoy, F. Artés, and C. Wang. 2004. Microbial and quality changes in minimally processed baby spinach leaves stored under super atmospheric oxygen and modified atmosphere conditions. Postharvest Biol. Technol. 33:51-59.

Berba, K. and M. Uchanski. 2012. Post-harvest physiology of microgreens. J. Young Investig. 24:1-5.

Bolin, H. and C. Huxsoll. 1989. Storage stability of minimally processed fruit. J. Food Process. Preserv. 13:281-292.

Chandra, D., J.G. Kim, and Y.P. Kim. 2012. Changes in microbial population and quality of microgreens treated with different sanitizers and packaging films. Hort. Environ. Biotechnol. 53:32-40.

Conway, W.S. 1987. The effects of postharvest infiltration of calcium, magnesium or strontium on decay, firmness, respiration and ethylene production in apples. J. Amer. Soc. Hort. Sci. 112:300-303.

Conway, W., C. Sams, and K. Hickey. 2002. Preand postharvest calcium treatment of apple fruit and its effect on quality. Acta Hort. 594:413-419.

Duque, P. and J. Arrabaça. 1999. Respiratory metabolism during cold storage of apple fruit. II. Alternative oxidase is induced at the climacteric. Physiol. Plant. 107:24-31.

Esmel, C., J. Duval, E. Simonne, and S. Sargent. 2004. The influence of preharvest calcium applications on postharvest quality and yield of 'Sweet Charlie' strawberry. HortScience 39:853.

Floros, J.D., A. Ekanayake, G.P. Abide, and P.E. Nelson. 1992. Optimization of postharvest dips in calcium chloride on strawberry. J. Agr. Food Chem. 4:30-33.

Holb, I.J., B. Balla, A. Vámos, and J.M. Gáll. 2012. Influence of preharvest calcium applications, fruit injury, and storage atmospheres on postharvest brown rot of apple. Postharvest Biol. Technol. 67:29-36.

Kou, L., Y. Luo, T. Yang, Z. Xiao, E.R. Turner, G.E. Lester, Q. Wang, and M.J. Camp. 2013. Postharvest biology, quality and shelf life of buckwheat microgreens. LWT-Food Sci. Technol. (Campinas.) 51:73-78.

Kou, L., T. Yang, Y. Luo, X. Liu, L. Huang, and E. Codling. 2014a. Pre-harvest calcium application increases biomass and delays senescence of broccoli microgreens. Postharvest Biol. Technol. 87:70-78.

Kou, L.Y., E. Luo, E.R. Park, A. Turner, W.M. Barczak, and I.I. Jurick. 2014b. Temperature abuse timing affects the rate of quality deterioration of commercially packaged ready-to-eat baby spinach. Part I: Sensoryanalysis and selected quality attributes. Postharvest Biol. Technol. 91:96-103.

Lee, J.S., J.G. Kim, and S. Park. 2009. Effects of chlorine wash on the quality and microbial population of 'Tah tasai' Chinese cabbage (Brassica campestris var. narinosa) microgreen. Korean J. Hort. Sci. 27:625-630.

Lester, G. and M. Grusak. 2001. Postharvest application of chelated and nonchelated calcium dip treatments to commercially grown honey dew melons: Effects on peel attributes, tissue calcium concentration, quality, and consumer preference following storage. HortTechnology 11:561-566. 
Lester, G. and M. Grusak. 2004. Field application of chelated calcium: Postharvest effects on cantaloupe and honeydew fruit quality. HortTechnology 14:29-38.

Luna-Guzmán, I. and D. Barrett. 2000. Comparison of calcium chloride and calcium lactate effectiveness in maintaining shelf stability and quality of fresh-cut cantaloupe. Postharvest Biol. Technol. 19:61-72.

Luo, Y., J. McEvoy, M. Wachtel, J. Kim, and Y. Huang. 2004. Package atmosphere affects postharvest biology and quality of fresh-cut cilantro leaves. HortScience 39:567-570.

Manganaris, G.A., M. Vasilakakis, I. Mignani, G. Diamantidis, and K. Tzavella-Klonari. 2005. The effect of preharvest calcium sprays on quality attributes, physicochemical aspects of cell wall components and susceptibility to brown rot of peach fruits (Prunus persica L. cv. Andross). Sci. Hort. 107:43-50.

Martín-Diana, A.B., D. Rico, C. Barry-Ryan, J.M. Frías, J. Mulcahy, and G.T.M. Henehan. 2005. Comparison of calcium lactate with chlorine as a washing treatment for fresh-cut lettuce and carrots: Quality and nutritional parameters. J. Sci. Food Agr. 85:2260-2268.

Meilgaard, M., G.V. Civille, and T. Carr. 1991. Sensory evaluation techniques. 2nd Ed. CRC Press Inc., Boca Raton, FL.

Meng, X., J. Han, Q. Wang, and S. Tian. 2009. Changes in physiology and quality of peach fruits treated by methyl jasmonate under low temperature stress. Food Chem. 114:10281035.

Mohammed, M., L.A. Wilson, and P.I. Gomes. 1991. Effects of postharvest dips on the storage quality of fruit from two hot pepper (Capicum frutenscens) cultivars. Trop. Agr. 68:81-87.

Palta, J. 1996. Role of calcium in plant responses to stresses: Linking basic research to the solution of practical problems. HortScience 31:51-57.

Poovaiah, B. 1986. Role of calcium in prolonging storage life of fruits and vegetables. Food Technol-Chicago. 40:86-89.

Raese, J. and S. Drake. 1993. Effects of preharvest calcium sprays on apple and pear quality. J. Plant Nutr. 16:1807-1819.

Rubinstein, B. 2000. Regulation of cell death in flower petals. Plant Mol. Biol. 44:303-318.

Saftner, R.A., J. Bai, J.A. Abbott, and Y.S. Lee. 2003. Sanitary dips with calcium propionate, calcium chloride, or a calcium amino acid chelate maintain quality and shelf stability of fresh-cut honeydew chunks. Postharvest Biol. Technol. 29:257-269.

Saftner, R., W. Conway, and C. Sams. 1998. Effects of postharvest clacium and fruit coating treatments on postharvest life, quality maintenance, and fruit-surface injury in 'Golden Delicious' apples. J. Amer. Soc. Hort. Sci. 123:294-298.
Simons, L. (ed.). 2001. New washing treatments for minimally processed vegetables. Food Science Australia, Sydney, Australia.

Souty, M., M. Reich, L. Breuils, Y. Chambroy, G. Jacquemin, and J. Audergon. 1995. Effects of postharvest calcium treatments on shelf-life and quality of apricot fruit. Acta Hort. 384:619-623.

Sun, J., L. Kou, P. Geng, H. Huang, T. Yang, Y. Luo, and P. Chen. 2015. Metabolomic assessment reveals an elevated level of glucosinolate content in $\mathrm{CaCl}_{2}$ treated broccoli microgreens. J. Agr. Food Chem. 63:1863-1868.

Torre, S., A. Borochov, and A. Halevy. 1999. Calcium regulation of senescence in rose petals. Physiol. Plant. 107:214-219.

Tsantili, E., D. Rouskas, M. Christopoulos, V. Stanidis, J. Akrivos, and D. Papanikolaou. 2007. Effects of two pre-harvest calcium treatments on physiological and quality parameters in 'Vogue' cherries during storage. J. Hort. Sci. Biotechnol. 82:657-663.

Watkins, C.B. and J.F. Nock. 2012. Production guide for storage of organic fruits and vegetables. NYS IPM Publ. 10, p. 3-4.

Xiao, Z., G.E. Lester, Y. Luo, and Q. Wang. 2012. Assessment of vitamin and carotenoid concentrations of emerging food products: Edible microgreens. J. Agr. Food Chem. 60:7644-7651.

Yang, H.H. and H.T. Lawsless. 2005. Descriptive analysis of divalent salts. J. Sens. Stud. 20:97-113. 